\title{
An exploratory study of sustainability evaluation in project management
}

\author{
Mauro Luiz Martens, Marly Monteiro de Carvalho \\ Polytechnic School University of São Paulo \\ e-mails: mauro.martens@usp.br; marlymc@usp.br
}

\begin{abstract}
Despite the increasing diffusion of project management, it is still incipient the discussion of issues related to sustainability in environmental, social and economic dimensions. This study aims to assess the integration of sustainability into project management. Was used as methodological approach an exploratory research through ex-post fact study conducted in two projects in the food service companies. Data were gathered through project documents and semi-structured interview with projects'stakeholders. As results are presented the evaluation tool of sustainability in projects, as well its practical application. It concludes that the pilot tool proposed presents a systematic logic with applicability for assessing sustainability in the context of project management. Finally, the results show a limited use of sustainability concepts in project management and which still the economic dimension overlaps the environmental and social dimensions.
\end{abstract}

Keywords: sustainability, project management, sustainability assessment, development sustainable.

\section{Introduction}

The concept of sustainability is linked to three dimensions: environmental, economic and social, in other words, sustainability with the Triple-Bottom Line vision (ELKINGTON, 1998; LABUSCHAGNE; BRENT; VAN ERCK, 2005). From this perspective, organizations, increasingly seeking excellence, are taken to develop ways to reduce the social and environmental impacts. In this context emerges the need for sustainability.

Carvalho and Rabechini Junior (2011) quote a survey, conducted in 2002, which showed that there is a gap in the management level of organizations with regard to the incorporation of sustainability aspects in the organizational processes. Similarly Labuschagne, Brent and Van Erck (2005) argue the need for environmental, social and economic dimensions be introduced and worked in the project management, aiming at sustainability.

The project management and sustainability issues have been the subject of numerous studies, but little has been seen on the convergence between both. Some initiatives integrate the themes (BODEA et al., 2010; JONES, 2006; TURLEA et al., 2010; VIFELL; SONERYD, 2012), but much is still needed to develop tools, techniques and methodologies (SINGH et al., 2011), which are of simple application in the context of routine in the function of project management (CARVALHO; RABECHINI JUNIOR, 2011).

The need for studies on the convergence of sustainability themes and project management, combined with the growing importance of both in the current business context, motivates the realization of this study, which seeks to contribute to the development of thematic sustainability in project management. Thus, this research focuses on the study of the alignment of these two topics, with the aim of evaluating the integration of sustainability concepts in project management. The methodological approach used was of exploratory study, by means of bibliographical research and ex-post facto research of two projects in companies in the sector of food service.

Following this introduction, in section 2 is made a literature review; in section 3 is presented the methodology; section 4 presents the preliminary sustainability assessment tool in project management and the results of its application in two projects; and, in section 5 are raised the final considerations.

\section{Sustainability and project management}

To initiate the understanding of business sustainability, it is necessary to understand the concept of sustainable development. As the document Our Common Future, developed by the World Commission on Environment and Development, the concept of sustainable development (SD) is one that meets the needs of the present without compromising the needs of future generations (WORLD..., 1987). The concept of SD, according to Araújo and Mendonça (2009), is synonymous of rational society, clean industries and economic growth. A broader concept of SD is based on the integration of three dimensions: social, environmental and economic, constituting the sustainability tripod, known as Triple-Bottom Line (TBL) which became widely known (ELKINGTON, 1998; KNOEPFEL, 2010; LABUSCHAGNE; BRENT; VAN ERCK, 2005; ARAÚJO; MENDONÇA, 2009; CARVALHO; RABECHINI JUNIOR, 2011). 
To contribute to sustainability, organizations should modify their production processes (ARAÚJO; BUENO, 2008), and this implies building production systems that do not cause negative impacts and offer products and services that contribute to the improvement of environmental performance. For Hubbard (2009), measuring organizational performance is not easy, especially with the concepts of sustainability having extended the scope of the measures, and this causes organizations to be concerned with sustainability reports and according to O'Dwyer and Owen (2005) it is a trend.

Sustainability reports help to integrate functions typically isolated from the company, such as finance, marketing and research and development, in a strategic way. The reporting of sustainability opens internal dialogues that could not occur otherwise (GLOBAL..., 2008). However, sustainability requires an integrated view of the world, with multidimensional indicators showing the interrelationships between the economy, the environment and society.

Some forms for the evaluation of business sustainability are already known: the Dow Jones Sustainability Indexes (2012) that has international credibility among corporations and has the focus of shareholders; the Global Reporting Initiative (GLOBAL..., 2012), which has international reach and focuses on the interest groups (stakeholders) and Ethos Institute (ETHOS, 2006), widely recognized in national territory, based on the GRI and IBASE (Brazilian Institute of Social and Economic Analysis).

One of the most used is the GRI, which is a longterm international process, with active participation of multiple interested parts, whose mission is to develop and disseminate Guidelines for Sustainability Reports, of global applicability. The guidelines are used voluntarily by organizations wishing to draw up reports on the economic, environmental and social dimensions of their activities, products and services. The objective is to assist the reporting organization and its interested parts to articulate and understand their contributions to sustainable development (GRI, 2008).

These initiatives of assessing sustainability practices in organizational context are the broad approach, without addressing specific organizational functions. Carvalho and Rabechini Junior (2011) remember the gap in the management level of organizations with regard to the incorporation of sustainability aspects in organizational processes, arguing the need for the incorporation of these concepts in project management function. This function of project management has assumed greater importance in companies (KERZNER, 2006), going through a process of transformation to be able to give answers increasingly effective and agile (CARVALHO; RABECHINI JUNIOR, 2011).

One of the ways of conducting projects is recommended by the Guide of Knowledge in Project Management
(PMBOK) which structure the project management in nine areas of essential knowledge (PROJECT..., 2008). They are: project integration, project scope, project time, project cost, project quality, human resources of the project, project design, project communications, project risk, project acquisitions. In addition, shows five groups of managerial process that interrelate with the areas of knowledge: initialization, planning, monitoring and control, execution and closure. Despite the popularization of knowledge guides in the area of projects, they do not devote special attention to sustainability area.

Project management, when it comes to sustainability, must understand the tension between the different groups of stakeholders and the trade-offs involved (CARVALHO; RABECHINI JUNIOR, 2011). To this end, the sustainability of a project depends on the competent management of its natural complexity, as well as their ability to consider business plans the legitimate interests of its various stakeholders and the impacts on the environment. According to this perspective, Buson et al. (2009), Labuschagne, Brent and Van Erck (2005), Ethos (2006) and Carvalho and Rabechini Junior (2011), suggest sustainability variables based on economic, social and environmental dimensions and that can be used for sustainability assessment in projects.

In addition, sustainability in project management can be explored in many other ways and companies that see it as a key element to your business and working with development and project management should be aware of the following points: sustainable shopping, develop analytical structure of projects that contemplate sustainability-related deliveries, use life cycle assessment project product, perform risk management of enterprises, considering the environmental and social risk category, and consider in the solution of the project elements and technologies that promote sustainability (CARVALHO; RABECHINI JUNIOR, 2011).

In this line of reasoning, the studies promoting this integration of sustainability concepts in project management, as well as systematic evaluation, become increasingly necessary in the business environment.

\section{Methodology}

This study is qualified as an exploratory research (GIL, 2006). This research aims to understand how sustainability themes are inserted in project management, through a bibliographical research and ex-post facto research. Ex-post facto research is a systematic and empirical research in which the researcher does not have direct control over the independent variables, because already occured or they are intrinsically not manipulated (GIL, 2006).

With the literature review was proposed a tool for analysis of insertion of sustainability in project management. The tool was applied by ex-post facto research in two projects of 
structuring of production and distribution of food and were selected by convenience and accessibility of researchers. The projects were developed between the months of July 2005 to July 2007, in small companies of the food service sector, located in the contryside of Rio Grande do Sul, Brazil.

The ex-post facto analysis of the projects was focused in the analysis of documentation, as well as semi-structured interview conducted with managers/coordinators of the projects. The interview and analysis of documents serve as sources of evidence from the study (YIN, 2005). The documentation analysis involved the initial diagnostics, budgets and the final reports of projects. To maintain the confidentiality of the information submitted and the names of the organizations, the projects were referred to as pro01 and pro02.

\section{Presentation of the results}

\subsection{Evaluation tool of sustainability}

The sustainability assessment tool proposal and used in this study is composed of three steps: (a) Understanding, (b) Evaluation and tab, and (c) Interpretation and corrective actions. Inside the steps, there are five stages: start the project, planning the project, run the project, monitor and control the project and close the project. The relationship between these five stages or groups of processes in the areas of knowledge in project management (integration, scope, time, costs, quality, human resources, communication, risks and acquisitions), results in a set of twenty two actions. In each of the actions, the aim is to highlight the concepts of Sustainability Tripod (ELKINGTON, 1998; LABUSCHAGNE; BRENT; VAN ERCK, 2005) through eighty five variables or questions to highlight elements of sustainability (PROJECT..., 2008; BUSON et al., 2009; GLOBAL..., 2008; ETHOS, 2006; CARVALHO; RABECHINI JUNIOR, 2011). Table 1 presents just one example of this relationship showing the closing phase of the project.

The step (a) Understanding shows a generic view of the flow of information suitable for the incorporation of the concepts of sustainability (ELKINGTON, 1998; LABUSCHAGNE; BRENT; VAN ERCK, 2005) in organizations. This information flow should be horizontal, permeating the organizational processes, and vertical, permeating strategic, managerial and operational levels (Figure 1).

Table 1. Evaluation of the variables of the sustainability dimensions of the project pro01: phase or group of closing processes and integration management area (example).

\begin{tabular}{|c|c|c|c|c|c|c|c|c|c|c|c|c|c|c|c|c|c|c|c|}
\hline \multirow{2}{*}{\begin{tabular}{|c|} 
PHASE \\
ACTION \\
\end{tabular}} & \multirow{2}{*}{\begin{tabular}{|c|} 
CLOSE THE PROJECT \\
22 CLOSURE STATEMENT \\
\end{tabular}} & \multicolumn{6}{|c|}{ Economic Dimension } & \multicolumn{6}{|c|}{ Environmental Dimension } & \multicolumn{6}{|c|}{ Social Dimension } \\
\hline & & 1 & 2 & 3 & 4 & 5 & N/A & 1 & 2 & 3 & 4 & 5 & N/A & 1 & 2 & 3 & 4 & 5 & N/A \\
\hline 79 & $\begin{array}{l}\text { Confirm if technical actitivities are } \\
\text { concluded and if results comply } \\
\text { with the scope }\end{array}$ & & & & & 1 & & & 1 & & & & & & 1 & & & & \\
\hline 80 & $\begin{array}{l}\text { Obtain formal acceptance of the } \\
\text { project's final results }\end{array}$ & & & & & 1 & & & & 1 & & & & & & 1 & & & \\
\hline 81 & $\begin{array}{l}\text { Report project end at the last status } \\
\text { meeting }\end{array}$ & & & & & 1 & & & 1 & & & & & & 1 & & & & \\
\hline 82 & $\begin{array}{l}\text { Organize the directory of project } \\
\text { documents for future reference }\end{array}$ & & & & 1 & & & 1 & & & & & & & 1 & & & & \\
\hline 83 & $\begin{array}{l}\text { Identify and document lessons } \\
\text { learnt }\end{array}$ & & & 1 & & & & & 1 & & & & & & 1 & & & & \\
\hline 84 & $\begin{array}{l}\text { Release the product or services for } \\
\text { the company's operation }\end{array}$ & & & & 1 & & & & 1 & & & & & & 1 & & & & \\
\hline 85 & Release the project team & & & & 1 & & & & 1 & & & & & & & 1 & & & \\
\hline & \begin{tabular}{|l|}
$\%$ TBL $=$ Sum of variables $\mathrm{x}$ \\
weight $\mathrm{x} 100 / \mathrm{n}$ variables
\end{tabular} & 0 & 0 & 42,9 & 171 & 214 & 0 & 14,3 & 143 & 42,9 & 0 & 0 & 0 & 0 & 143 & 85,7 & 0 & 0 & 0 \\
\hline & $\%$ Total of the domain & \multicolumn{5}{|c|}{85,71428571} & & \multicolumn{5}{|c|}{40} & & \multicolumn{5}{|c|}{45,71428571} & \\
\hline & $\begin{array}{l}\% \text { Total of the dimension TBL in } \\
\text { the PHASE }\end{array}$ & \multicolumn{18}{|c|}{57,14285714} \\
\hline & $\%$ Total of the domain & \multicolumn{5}{|c|}{61,00445471} & & \multicolumn{5}{|c|}{30,20859358} & & \multicolumn{5}{|c|}{32,56690315} & \\
\hline \multicolumn{2}{|c|}{$\begin{array}{l}\text { \% TOTAL OF TBL SUSTAINABILITY IN } \\
\text { THE PROJECT }\end{array}$} & \multicolumn{18}{|c|}{41,25998382} \\
\hline
\end{tabular}

Source: Based on PMI (PROJECT..., 2008), Elkington (1998), Labuschagne, Brent and Van Erck (2005), Buson et al. (2009), GRI (GLOBAL... 2008), ETHOS (2006) and Carvalho and Rabechini Junior (2011). 


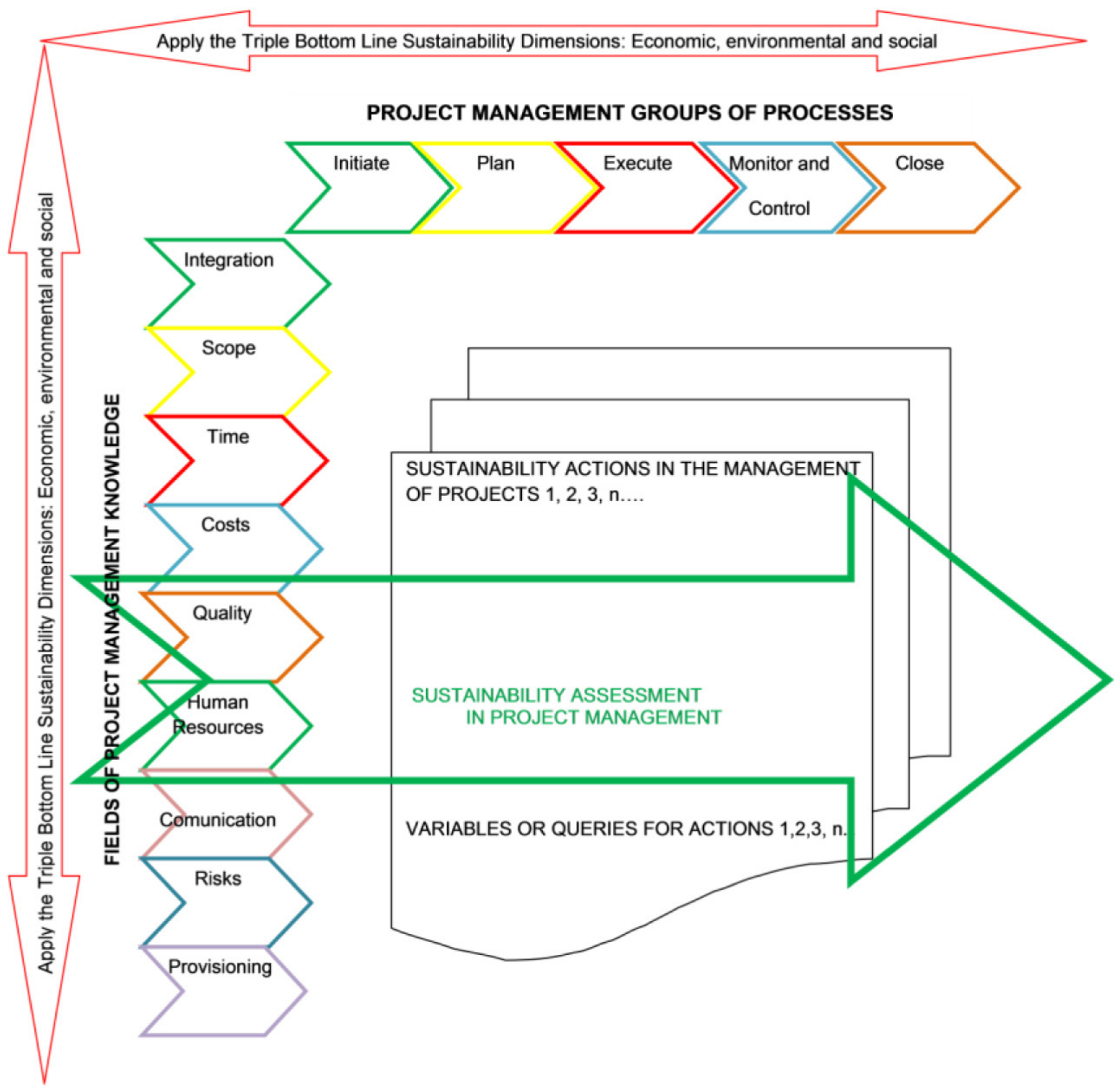

Figure 1. Sustainability assessment tool in projects. Source: Based on PMI (PROJECT..., 2008), Elkington (1998), Labuschagne, Brent and Van Erck (2005), Buson et al. (2009), GRI (GLOBAL..., 2008), ETHOS (2006) and Carvalho and Rabechini Junior (2011).

Traditionally, the project management function is located in the organizational management level, but with some part situated outside the borders of the organization, showing a position where the function of project management needs to make the connection between the stakeholders. The understanding of horizontal and vertical information flow must be applied in the project management function and this line of reasoning can be understood as the set of groups of processes and areas of knowledge in project management (PROJECT..., 2008), illustrated in Figure 1.

In this sense, splitting the role of projects in their groups of project management processes, it can be understood that the TBL dimension of sustainability permeates the actions as the direction of its flow of information. It is used an appropriateness of the relationship between knowledge areas and processes proposed by PMI (PROJECT..., 2008), but highlighting the TBL information flow. The position of the actions arising out of this relationship is displayed in Figure 1.

Starting from the actions identified in the relationship between the groups of processes and the areas of knowledge in project management, variables and questions are presented for each action, and thus, one can assess the sustainability in the projects. This vision of sustainability 
measurement of variables or questions of sustainability in project management is displayed in Table 1.

In step (b) Evaluation and tab, the variables or questions for each action resulting from the relationship between process groups and areas of knowledge in project management are exposed for measurement. These variables of sustainability dimensions will be assessed for each project individually. In each issue will be posted the evaluation condition according to a Likert scale of five points, where the notes represent: (1) failure to (5) total compliance and, in cases of difficult measurement, (N/A) does not apply.

A table of evaluation using the Excel software, as example of Table 1 presents the analysis of the project pro1 for the phase or group of project closure process, in the area of knowledge management integration. For each variable or questioning of sustainability, by Likert scale, is punctuated a note percentage by TBL dimension and after the total percentage of the three dimensions of the process group or tool phase in relation to the alignment to the sustainable design philosophy.

In the end is calculated the average of the percentage notes of each of the three TBL dimensions of phase or group of process concerned, as well as is calculated the overall average of alignment to the TBL of all five stages of the tool. After these results are tabulated and displayed graphically.

In step (c) Interpretations and taking corrective actions, it was highlighted the importance of interdependence and commitment of project participants in all phases of the project Lifecycle. It is worth noting that with ex-post facto analysis of the projects, the potential of corrective action analysis is limited, but the discussion of results in partial evaluations can maximize the final results on sustainability.

The proposed tool provides two forms of conduct the interpretations of the evaluations performed. At first, the project manager can use the tool to evaluate since the first action of the project initiation phase, or also at any point in the timeline of the project. It the second form, the manager can use the evaluation at the end of the project for benchmarking with other projects of the organization and planning of new actions.

With the tabulation of the data, the goal is to offer the project manager and the team the possibility of constantly questioning the actions (ARGYRIS, 1992) related to process groups in the areas of knowledge. This cycle leads to continuous personal and collective learning because people learn faster when they have a real sense of responsibility for their actions and that leads to the closing of the cycle, requiring that the team is critical to rewind or forward the project, taking actions legible (SENGE, 1999). For the regular use of this tool, those responsible for conducting the evaluation should be prepared, trained and independent and should not assess their own tasks while working on the projects under analysis.

\subsection{Cross-analysis of evaluation of projects}

The application of the tool in two projects provided verification of its applicability to evaluate the insertion of sustainability in project management and obtain individual results of each phase of the project, as shown in Figure 2.

With these results it can be evidenced that process groups, plan and monitor/control the project, show less effort in sustainability, with respectively $32 \%$ and $34 \%$ of TBL alignment. To stage or process group to terminate the project is where more efforts in sustainability, with $58 \%$ of TBL alignment. This shows an important point to be treated in future research, because the groups of project planning and monitoring need care, regarding the incorporation of sustainability variables in the design and control of projects.

From the results shown in Figure 3 we can see that the overall average perceived sustainability in both projects
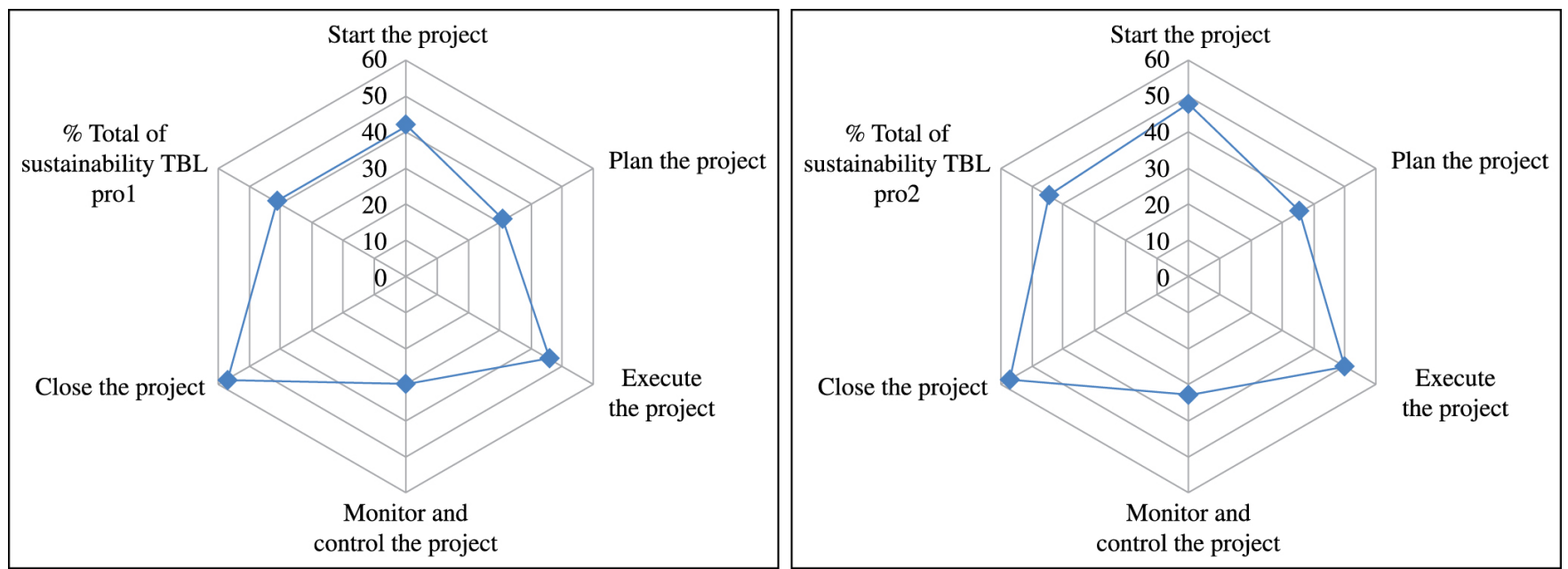

Figure 2. Results from the evaluation of sustainability on the process groups. Source: Prepared by the authors. 

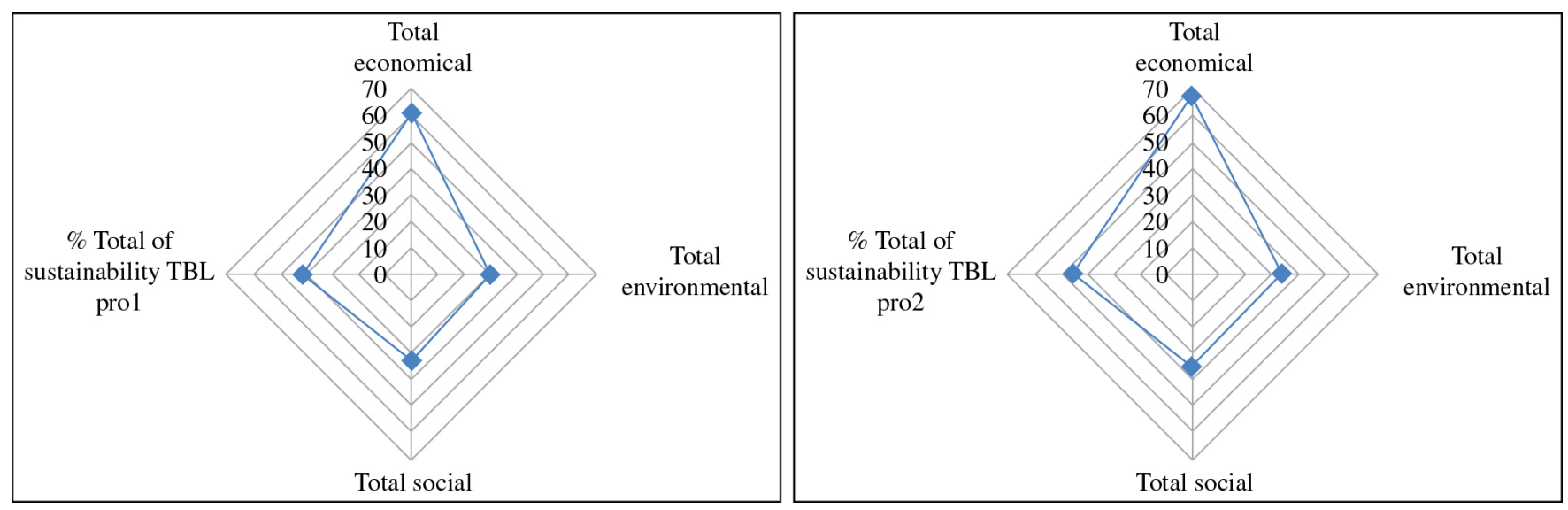

Figure 3. General results from the evaluation of sustainability in both sample projects. Source: Prepared by the authors.

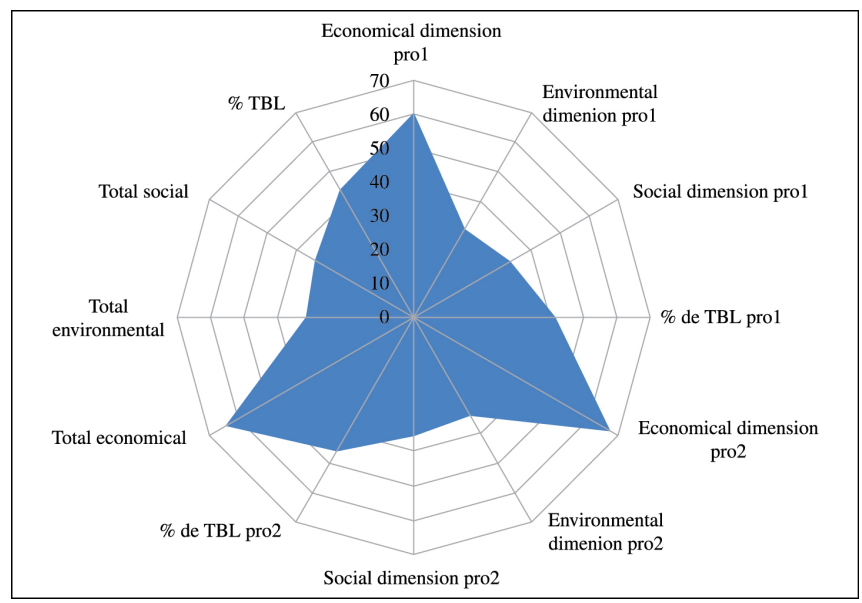

Figure 4. Results for sustainability dimension in both projects evaluated. Source: Prepared by the authors.

were $43 \%$. In addition, the dimension better evaluated was the economic dimension with $64.2 \%$, and this can be seen in Figure 4 below.

These responses show that in fact these companies act with the right alignment of the economic dimension of sustainability in its processes. According to the responsible pro01 "... this can be understood as true from a business reality facing the survival in economic terms in the environment of micro and small enterprises". Already the environmental dimensions (31.9\% on average) and social (33.9\% on average) are not very expressive in projects, since the resources for investment in the incorporation of environmental and social dimensions in projects are difficult allocation (LABUSCHAGNE; BRENT; VAN ERCK, 2005).

\section{Final remarks}

The central concepts of research, sustainability, project management and the need for integration of TBL sustainability concepts in project management practices, showed that in fact these themes are expressive in actuality and deserve the attention of the researchers. Motivated by this need, the present research aimed to evaluate the integration of sustainability concepts in project management. With the conceptual line studied was possible to organize the ideas cited in the text, to present a proposal of tool and evaluate sustainability in two projects.

It was concluded that the projects evaluated lack actions in terms of sustainability, that is, actions and practices were observed or indicators of economic, environmental and social sustainability in the management of the projects evaluated adding $43 \%$ TBL alignment. It is important to note that the economic dimension with $64.2 \%$, overlaps social and environmental dimensions (with $33 \%$ on average), that still deserve attention and most dedicated investment, as stated by Labuschagne, Brent and Van Erck (2005).

However, the application of the tool, even with the limitation the fact that variables or questions have not been previously validated, presented applicability for assessing the sustainability of projects, as well as the metrics and variables proposals for collection the responses presented alignment to the organizational practices. With this, it is considered the primary tool applicable for its purpose. Thus, the proposed tool and its application can be considered as a contribution to the practice and to the academy.

In addition, the results of this study confirm the need to continue the efforts to discuss the subjects of project management and sustainability in the context of projects, as well as refine the tool using the same replication in other representative samples of projects in medium and large organizations, national or international, and thus contribute to the improvement and validation of a tool. Additionally, it is recommended to carry out researches that propose variables or questions validation to extract sustainability actions. Similarly, are recommended studies in-depth, in the form of case studies, to better understand the reality experienced by organizations, as well as survey type studies 
in the food sector, both in services as in the industrial sector, about sustainability in project management.

In addition to the variables or sustainability issues not previously validated, another limitation of the research is the choice of two projects, which took place for accessibility and convenience. Anyway (GIL, 2006) states that this choice, even though a less strict sampling type, applies in exploratory studies where no high level of precision is required.

Finally, based on studies already carried out, it is noticed that the insertion of sustainability concepts in the context of project management, can result in increasingly sustainable projects, on the optics of product, process and technology. Thus, with products and sustainable projects, organizations tend to get increasingly competitive advantages.

\section{Acknowledgments}

This research was supported by grants from the CNPq and from the CAPES.

\section{References}

ARAÚJO, G. C.; BUENO, M. P. Um estudo sobre a sustentabilidade empresarial na agroindústria frigorífica. Revistas Gerenciais, v. 7, n. 2, p. 147-154, 2008.

ARAÚJO, G. C.; MENDONÇA, P. S. M. Análise do processo de implantação das normas de sustentabilidade empresarial. Revista de Administração Mackenze, v. 10, n. 2, 2009.

ARGYRIS, C. Enfrentando defesas empresariais. Rio de Janeiro: Campus, 1992.

BODEA, C. et al. An Ontological-Based Model For Competences In Sustainable Development Projects : A Case Study For Project's. Economic Interferences, v. 12, n. 27, p. 177-189, 2010.

BUSON, M. A. et al. Uma proposta de avaliação da sustentabilidade de projetos na fase de planejamento com base nos princípios lean: um estudo de caso no segmento de eletrônicos. In: CONGRESSO BRASILEIRO DE GESTÃO DE DESENVOLVIMENTO DE PRODUTO, 2009, São José dos Campos. Anais... São José dos Campos, 2009.

CARVALHO, M. M.; RABECHINI JUNIOR, R. Fundamentos em Gestão de Projetos: Construindo competências para gerenciar projetos: teoria e casos. 3. ed. São Paulo: Atlas, 2011. $422 \mathrm{p}$.

DOW JONES SUSTAINABILITY INDEXES - DJSI. Available from: <http://www.sustainability-index.com>. Access in: 21 Apr 2012.

ELKINGTON, J. Canibals with forks: the triple bottom line of 21 st century business. Canadá: New Society Publishers, 1998.

ETHOS. Instituto Ethos de Empresas e Responsabilidade Social. Conferência Internacional do Instituto Ethos. 2006.
Available from: <http://www.ethos.org.br>. Access in: 21 Apr 2012.

GIL, A. C. Métodos e técnicas de pesquisa social. São Paulo: Atlas, 2006.

GLOBAL REPORTING INITIATIVE - GRI. 2008. Available from: <www.globalreporting.org>. Access in: 19 Apr 2012.

HUBBARD, G. Measuring Organizational Performance: Beyond the Triple Bottom Line. Business Strategy and the Environment, v. 19, p. 177-191, 2009. http://dx.doi. org/10.1002/bse.564

JONES, B. Trying harder: Developing a new sustainable strategy for the UK. Natural Resources Forum, v. 30, n. 2 , p. 124-135, 2006. http://dx.doi.org/10.1111/j.14778947.2006.00165.x

KERZNER, H. Gestão de projetos - as melhores práticas. 2. ed. Porto Alegre: Bookman, 2006.

KNOEPFEL, H. Survival and Sustainability as Challenges for Projects. Zurich: International Project Management Association, 2010.

LABUSCHAGNE, C.; BRENT, A. C.; VAN ERCK, R. Assessing the sustainability performances of industries. Journal of Cleaner Production, v. 3, n. 4, p. 373385, 2005. http://dx.doi.org/10.1016/j.jclepro.2003.10.007

O'DWYER, B.; OWEN, D. Assurance statement practice in environmental, social and sustainability reporting: a critical evaluation. British Accounting Review, v. 37, p. 205229, 2005. http://dx.doi.org/10.1016/j.bar.2005.01.005

PROJECT MANAGEMENT INSTITUTE - PMI. Um Guia do Conhecimento em Gerenciamento de Projetos (GUIA PMBOK). 4. ed. Pensilvânia: PMI, 2008.

SENGE, P. A quinta disciplina: arte e prática da organização de aprendizagem. 4. ed. São Paulo: Best Seller, 1999.

SINGH, R. et al. An overview of sustainability assessment methodologies. Ecological Indicators, v. 15, n. 1, p. 281299, 2011. http://dx.doi.org/10.1016/j.ecolind.2011.01.007

TURLEA, C. et al. The project management and the need for sustainable development. Metalurgia Internacional, v. 15, n. 3, p. 121-125, 2010.

VIFELL, Ã. C.; SONERYD, L. Organizing Matters: How "the Social Dimension" Gets Lost in Sustainability Projects. Sustainable Development, v. 20, n. 1, p. 18-27, 2012. http:// dx.doi.org/10.1002/sd.461

WORLD COMISSION ON ENVIRONMENT AND DEVELOPMENT - WECD. Our Common Future. Oxford: Oxford University Press; 1987.

YIN, R. K. Estudo de caso: planejamento e métodos. $3^{\text {a }}$ Ed. Porto Alegre: Bookman, 2005. 